\title{
Bio Efficacy of Bio Agents and Botanicals against Alternaria alternata (Fr.) Keissler Causing Leaf Spot of Pomegranate
}

\author{
Vasudha A. Kadam ${ }^{1 *}$, D.N. Dhutraj ${ }^{1}$, D.V. Pawar ${ }^{1}$ and D.D. Patil ${ }^{2}$ \\ ${ }^{1}$ Department of Plant Pathology, Vasantrao Naik Marathwada Krushi Vidhyapeeth, \\ Parbhani-431402, Maharashtra, India \\ ${ }^{2}$ Department of Agricultural Meteorology, B. A. College of Agriculture, \\ Anand Agricultural University, Anand- 388 110, Gujarat, India
}

*Corresponding author

\section{A B S T R A C T}

\section{Key words \\ Alternaria \\ alternata, \\ Pomegranate, Bio \\ agents, Botanicals \\ Article Info \\ Accepted: \\ 10 October 2018 \\ Available Online: \\ 10 November 2018}

\begin{abstract}
Pomegranate (Punica granatum L) is one of the important fruit crops grown in India. Leaf spot of pomegranate caused by Alternaria alternata (Fr.) Keissler has becoming a major limiting factor in cultivation of pomegranate in some regions of India. The present investigation was carried out to test the efficacy of bio-agents and botanicals in vitro. All the seven fungal and two bacterial antagonists tested, exhibited significant mycelial growth inhibition of $A$. alternata. However, T. viride recorded significantly highest mycelial growth inhibition $(86.85 \%)$ of the test pathogen, followed by $T$. hamatum $(82.04 \%), A$. niger $(81.11 \%)$. Among eleven botanicals tested, significantly highest average mycelial growth inhibition was recorded with A. sativum (75.56\%), followed by Z. officinale (73.64 $\%)$, A. indica $(71.17 \%)$.
\end{abstract}

\section{Introduction}

Pomegranate (Punica granatum L.) is an ancient, delicious fruits consumed worldwide, gaining lot of attention of the world over, because of its high economic value and nutritional values. It is one of the important fruit crops in arid and semi-arid regions commercially important in both tropical and subtropical countries known for its drought tolerance which thrives well in dry tropical conditions with marginal soils of low fertility. Being the most adaptable subtropical fruit crop, its cultivation has increased rapidly creating its image as an important cash crop in global market. Globally India is ranked first in area and production. During 2015-16, pomegranate was cultivated over 2.09 lakh ha with an annual production of 24.42 lakh MT and productivity of $12.00 \mathrm{MT} / \mathrm{ha}$ in India (Anonymous, 2016). Maharashtra considered as pomegranate basket of India contributes more than 70 per cent of the total area under pomegranate followed by Andhra Pradesh, Uttar Pradesh, Rajasthan, Gujarat and Karnataka which are the leading states; cultivating pomegranate commercially on a large scale. 
However, the crop is under threat due to number of serious diseases such as bacterial blight (Xanthomonas axonopodis pv. punicae), wilt due to Ceratocystis fimbriata, anthracnose (Colletotrichum gloeosporioides) and leaf spot and severe fruit rotting due to Alternaria alternata, Cercospora sp., Pseudocercospora sp., Drechslera sp. and Sphaceloma sp.etc., are more or less equally important and harmful in some orchards and also take a heavy toll on the crop (Khosla and Bhardwaj, 2013). Among these; severe spotting and fruit rotting due to Alternaria alternata $(\mathrm{Fr}$.) Keissler; remains hitherto unexplored but potentially dangerous pathogen on pomegranate and considered to be an emerging disease.

In recent years, there has been a major thrust on pesticide residue free organic pomegranate production. Taking the task into consideration, efficient botanicals and bioagents need to be explored to fit into the management schedule. Use of bioagents for the management of various diseases of crop plants is eco-friendly and environmentally safe. Therefore, present investigation aimed to evaluate bioagents and botanicals (in vitro) against Alternaria alternata (Fr.) Keissler causing leaf spot of Pomegranate.

\section{Materials and Methods}

\section{Invitro evaluation of bioagents}

Seven fungal and two bacterial bioagents were evaluated in vitro against A. alternata, applying Dual Culture Technique (Dennis and Webster, 1971). Seven days old cultures of the test bioagents and test pathogen (A. alternata) grown on PDA were used for the study. Two 5 $\mathrm{mm}$ culture discs, one each of the test pathogen and test bioagent were cut out with sterilized cork borer and placed at equidistance, exactly opposite to each other on autoclaved and solidified PDA medium in Petri plates and three plates were incubated at
$27 \pm 2{ }^{0} \mathrm{C}$. PDA plates inoculated alone with pure culture disc $(5 \mathrm{~mm})$ of the test pathogen were maintained as untreated control. Pure cultures and talc based formulations of biocontrol agents viz., Trichoderma viride, $T$. hamatum, T. harzianum, T. (Gliocladium) virens, T. koningii, T. longibrachiatum, Aspergillus niger, Pseudomonas fluorescens and Bacillus subtilis were obtained from the Spawn Production-cum-Biocontrol Laboratory, Department of Plant Pathology, College of Agriculture, VNMKV, Parbhani; maintained and multiplied on appropriate culture media and used for present studies.

Observations on linear mycelial growth of the test pathogen and test bioagent were recorded at an interval of 24 hours and continued till untreated control plates were fully covered with mycelial growth of the test pathogen. Per cent inhibition of the test pathogen with the test bioagent, over untreated control was calculated by applying following formula (Arora and Upaddhyay, 1978).

Per cent Growth Inhibition =

Colony growth in _ Colony growth in Control plate intersecting plate X100

Colony growth in control plate

\section{In vitro evaluation of plant extracts}

Aqueous extracts of 11 botanicals (as detailed under treatments) were evaluated in vitro against A. alternata. Leaf / bulb / rhizome extract of the test botanicals were prepared by grinding with mixture-cum grinder. Washed $100 \mathrm{~g}$ each leaves / Turmeric rhizome / Onion bulb / Garlic cloves were macerated separately in $100 \mathrm{ml}$ distilled water $(\mathrm{w} / \mathrm{v})$ and the macerates obtained were filtered separately through double layered muslin cloth. Each of the filtrate obtained was further filtered through Whatman No. I filter paper using funnel and volumetric flasks (100 ml cap.). 
The final clear extracts obtained formed the standard plant extracts of 100 per cent concentration. These were evaluated (each @ $10 \%, 15 \%$ and $20 \%$ ) in vitro against $A$. alternata, applying Poisoned Food Technique (Nene and Thapliyal, 1993) and using Potato dextrose agar (PDA) as basal culture medium. An appropriate quantity of each test aqueous extract $(100 \%)$ was separately mixed thoroughly with autoclaved and cooled (40 0C) PDA medium in conical flasks $(250 \mathrm{ml}$ cap.) to obtain desired concentrations of 10 , 15 and 20 per cent. The PDA medium amended separately with the test aqueous extract was then poured $(20 \mathrm{ml} /$ plate $)$ into sterile glass Petri plates $(90 \mathrm{~mm}$ dia. $)$ and allowed to solidify at room temperature. For each test botanical extract and their respective concentrations, three plates / treatment / replication were maintained and all the treatments were replicated thrice. Upon solidification of the amended PDA medium, all the treatment plates were aseptically inoculated by placing in the centre a $5 \mathrm{~mm}$ mycelial disc obtained from a week old actively growing pure culture of $A$. alternata. Plates containing plain PDA without any botanical extract and inoculated with mycelial disc of the test pathogen served as untreated control. All these plates were then incubated at $27 \pm 2{ }^{\circ} \mathrm{C}$ temperatures for a week or till the untreated control plates were fully covered with mycelial growth of the test pathogen.

Observations on radial mycelial growth / colony diameter of the test pathogen were recorded treatment-wise at 24 hours interval and continued till mycelial growth of the test pathogen was fully covered in the untreated control plates. Per cent inhibition of mycelial growth over untreated control was calculated by applying the formula given by Vincent (1927)

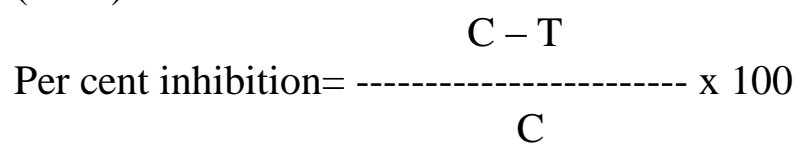

Where, $\mathrm{C}=$ growth of the test fungus in untreated control plates

$\mathrm{T}=$ growth of the test fungus in treated plates

\section{Results and Discussion}

\section{In vitro evaluation of bioagents}

Results (Plate 1, Fig. 1 and Table 1) revealed that all the bioagents evaluated exhibited fungistatic / antifungal activity against $A$. alternata and significantly inhibited its growth over untreated control. Of the seven fungal antagonists tested, T. viride was found most effective and test pathogen recorded least linear mycelial growth $(11.83 \mathrm{~mm})$ with highest mycelial inhibition $(86.85 \%)$ of the test pathogen. The second and third best antagonists found were T. hamatum and $A$. niger, which recorded mycelial growth of $16.17 \mathrm{~mm}$ and $17.00 \mathrm{~mm}$, of the test pathogen respectively and inhibition of 82.04 and 81.11 per cent, respectively.

This was followed by T. harzianum (col. dia.: $20.33 \mathrm{~mm}$ and inhibition: $77.41 \%), T$. (Gliocladium) virens (col. dia.: $23.67 \mathrm{~mm}$ and inhibition: $73.23 \%$ ) and T. longibrachiatum (col. dia.: $32.67 \mathrm{~mm}$ and inhibition: $63.70 \%$ ). The antagonists Pseudomonas fluorescens and Bacillus subtilis were found least effective with $47.17 \mathrm{~mm}$ and $37.83 \mathrm{~mm}$ linear mycelial growth and 47.59 and 57.96 per cent mycelial inhibition.

These results are in conformity with the earlier findings of those workers who reported bioagents viz., $T$. viride, T. harzianum, $T$. koningii and $T$. hamatum had significantly inhibited mycelial growth of A. alternata infecting different crops (Gohel et al., 2011; Akbari and Parakhia, 2007; Hudge et al., 2009; Waghunde et al., 2009; Balai and Ahir, 2011, Rajput et al., 2011; Apet et al., 2014). 
Table.1 In vitro evaluation of bio control agents against mycelial growth of $A$. alternate

\begin{tabular}{|c|c|c|c|}
\hline Tr. No. & Treatments & Colony Dia. of test pathogen $*(\mathrm{~mm})$ & $\%$ Inhibition \\
\hline \multicolumn{4}{|c|}{ Fungal antagonists } \\
\hline $\mathbf{T}_{1}$ & Trichoderma viride & 11.83 & $\begin{array}{c}86.85 \\
(68.71)\end{array}$ \\
\hline $\mathbf{T}_{2}$ & T. hamatum & 16.17 & $\begin{array}{c}82.04 \\
(64.90)\end{array}$ \\
\hline $\mathbf{T}_{\mathbf{3}}$ & T. harzianum & 20.33 & $\begin{array}{c}77.41 \\
(61.60)\end{array}$ \\
\hline $\mathbf{T}_{4}$ & G. virens & 23.67 & $\begin{array}{c}73.70 \\
(59.13)\end{array}$ \\
\hline $\mathbf{T}_{5}$ & T. konigii & 29.50 & $\begin{array}{c}67.22 \\
(55.05)\end{array}$ \\
\hline $\mathbf{T}_{6}$ & T. longi brachiatum & 32.67 & $\begin{array}{c}63.70 \\
(52.93)\end{array}$ \\
\hline $\mathbf{T}_{7}$ & Aspergillus niger & 17.00 & $\begin{array}{c}81.11 \\
(64.22)\end{array}$ \\
\hline \multicolumn{4}{|c|}{ Bacterial antagonist } \\
\hline $\mathbf{T}_{8}$ & Bacillus subtilis & 37.83 & $\begin{array}{c}57.96 \\
(49.56)\end{array}$ \\
\hline $\mathbf{T}_{9}$ & Pseudomonas fluorescens & 47.17 & $\begin{array}{c}47.59 \\
(43.60)\end{array}$ \\
\hline \multirow[t]{4}{*}{$\mathbf{T}_{10}$} & Control (Untreated) & 90.00 & $\begin{array}{c}0.00 \\
(0.00)\end{array}$ \\
\hline & S.E. \pm & 0.45 & 0.33 \\
\hline & C.D. $(P=0.01)$ & 1.338 & 0.99 \\
\hline & & 2.391 & 1.11 \\
\hline
\end{tabular}

*: Mean of three replications, Dia.: Diameter,

Figures in parentheses are arcsine transformed values 
Table.2 In vitro evaluation of plant extracts against mycelial growth ofA. Alternate

\begin{tabular}{|c|c|c|c|c|c|c|c|c|c|}
\hline \multirow{2}{*}{$\begin{array}{l}\text { Tr. } \\
\text { No. }\end{array}$} & \multirow[t]{2}{*}{ Treatment } & \multicolumn{3}{|c|}{ Col. Dia.(mm) *at Conc. } & \multirow{2}{*}{$\begin{array}{l}\text { Av. Col. } \\
\text { Dia.(mm) }\end{array}$} & \multicolumn{3}{|c|}{$\%$ Inhibition* } & \multirow{2}{*}{$\begin{array}{c}\text { Av. \% } \\
\text { Inhibition }\end{array}$} \\
\hline & & $10 \%$ & $15 \%$ & $20 \%$ & & $10 \%$ & $15 \%$ & $20 \%$ & \\
\hline $\mathbf{T}_{1}$ & $\begin{array}{l}\text { Neergudi } \\
\text { (V. negundo) }\end{array}$ & 44.33 & 41.00 & 38.33 & 41.22 & $\begin{array}{c}50.74 \\
(45.41)\end{array}$ & $\begin{array}{c}54.44 \\
(47.53)\end{array}$ & $\begin{array}{c}57.41 \\
(49.24)\end{array}$ & $\begin{array}{c}54.20 \\
(47.39)\end{array}$ \\
\hline $\mathbf{T}_{2}$ & $\begin{array}{l}\text { Bougainvillea } \\
\text { (Bougainveilliea spp.) }\end{array}$ & 77.17 & 72.67 & 66.67 & 72.17 & $\begin{array}{l}14.26 \\
(22.17)\end{array}$ & $\begin{array}{l}19.26 \\
(26.02)\end{array}$ & $\begin{array}{c}25.93 \\
(30.60)\end{array}$ & $\begin{array}{c}19.81 \\
(26.26)\end{array}$ \\
\hline $\mathbf{T}_{\mathbf{3}}$ & $\begin{array}{l}\text { Dhotra / Dhatura } \\
\text { (D. metal) }\end{array}$ & 43.67 & 39.83 & 34.33 & 39.28 & $\begin{array}{c}51.48 \\
(45.83)\end{array}$ & $\begin{array}{c}55.74 \\
(48.28)\end{array}$ & $\begin{array}{c}61.85 \\
(51.84)\end{array}$ & $\begin{array}{c}56.36 \\
(48.65)\end{array}$ \\
\hline $\mathbf{T}_{4}$ & $\begin{array}{l}\text { Nilgiri/Eucalyptus } \\
\text { (E. globulus) }\end{array}$ & 35.67 & 30.67 & 24.50 & 30.28 & $\begin{array}{c}60.37 \\
(50.97)\end{array}$ & $\begin{array}{c}65.93 \\
(54.27)\end{array}$ & $\begin{array}{c}72.78 \\
(58.53)\end{array}$ & $\begin{array}{c}66.36 \\
(54.59)\end{array}$ \\
\hline $\mathbf{T}_{\mathbf{5}}$ & $\begin{array}{l}\text { Ghaneri } \\
\text { (L. camera) }\end{array}$ & 48.50 & 45.00 & 39.67 & 44.39 & $\begin{array}{c}46.11 \\
(42.75)\end{array}$ & $\begin{array}{c}50.00 \\
(44.98)\end{array}$ & $\begin{array}{c}55.93 \\
(48.39)\end{array}$ & $\begin{array}{c}50.68 \\
(45.37)\end{array}$ \\
\hline $\mathbf{T}_{6}$ & $\begin{array}{l}\text { Ginger } \\
\text { (Z. officinale) }\end{array}$ & 26.67 & 24.17 & 20.33 & 23.72 & $\begin{array}{c}70.37 \\
(57.00)\end{array}$ & $\begin{array}{c}73.15 \\
(58.77)\end{array}$ & $\begin{array}{c}77.41 \\
(61.60)\end{array}$ & $\begin{array}{c}73.64 \\
(59.12)\end{array}$ \\
\hline $\mathbf{T}_{7}$ & $\begin{array}{l}\text { Karanj } \\
\text { (P.pinnata) }\end{array}$ & 60.67 & 52.50 & 47.83 & 53.67 & $\begin{array}{c}32.59 \\
(34.80)\end{array}$ & $\begin{array}{c}41.67 \\
(40.19)\end{array}$ & $\begin{array}{c}46.85 \\
(43.18)\end{array}$ & $\begin{array}{c}40.37 \\
(39.39)\end{array}$ \\
\hline $\mathbf{T}_{8}$ & $\begin{array}{l}\text { Neem } \\
(\text { A. indica })\end{array}$ & 30.00 & 25.17 & 22.67 & 25.94 & $\begin{array}{c}66.67 \\
(54.72)\end{array}$ & $\begin{array}{c}72.04 \\
(58.06)\end{array}$ & $\begin{array}{c}74.81 \\
(59.85)\end{array}$ & $\begin{array}{c}71.17 \\
(57.54)\end{array}$ \\
\hline $\mathbf{T}_{9}$ & $\begin{array}{l}\text { Parthenium } \\
\text { (P.hysterophorus) }\end{array}$ & 67.33 & 59.33 & 53.33 & 60.00 & $\begin{array}{c}25.19 \\
(30.10)\end{array}$ & $\begin{array}{c}34.07 \\
(35.70)\end{array}$ & $\begin{array}{c}40.74 \\
(39.65)\end{array}$ & $\begin{array}{c}33.33 \\
(35.15)\end{array}$ \\
\hline $\mathbf{T}_{10}$ & $\begin{array}{l}\text { Turmeric } \\
\text { (C.longa) }\end{array}$ & 42.33 & 35.33 & 29.83 & 35.83 & $\begin{array}{c}52.96 \\
(46.68)\end{array}$ & $\begin{array}{c}60.74 \\
(51.18)\end{array}$ & $\begin{array}{c}66.85 \\
(54.83)\end{array}$ & $\begin{array}{c}60.19 \\
(50.90)\end{array}$ \\
\hline $\mathbf{T}_{11}$ & $\begin{array}{l}\text { Garlic } \\
\text { (A. sativum) }\end{array}$ & 24.83 & 22.67 & 18.50 & 22.00 & $\begin{array}{c}72.41 \\
(58.29)\end{array}$ & $\begin{array}{c}74.81 \\
(59.85)\end{array}$ & $\begin{array}{c}79.44 \\
(63.01)\end{array}$ & $\begin{array}{l}75.56 \\
(60.39)\end{array}$ \\
\hline $\mathbf{T}_{12}$ & Control & 90.00 & 90.00 & 90.00 & 90.00 & $\begin{array}{c}0.00 \\
(0.00)\end{array}$ & $\begin{array}{c}0.00 \\
(0.00)\end{array}$ & $\begin{array}{c}0.00 \\
(0.00)\end{array}$ & $\begin{array}{c}0.00 \\
(0.00)\end{array}$ \\
\hline & S.E. \pm & 0.51 & 0.48 & 0.44 & & 0.36 & 0.32 & 0.33 & \\
\hline & C.D. $(P=0.01)$ & 1.49 & 1.40 & 1.30 & & 1.05 & 0.95 & 0.96 & \\
\hline & & 1.78 & 1.84 & 1.89 & & 1.52 & 1.28 & 1.30 & \\
\hline
\end{tabular}

* Mean of three replications, Figures in parentheses are arcsine transformed value, Dia: Diameter Conc.: Concentration, Av.: Average, Col.: Colony 
Plate.1 In vitro effect of bioagents on growth and inhibition of A. alternate

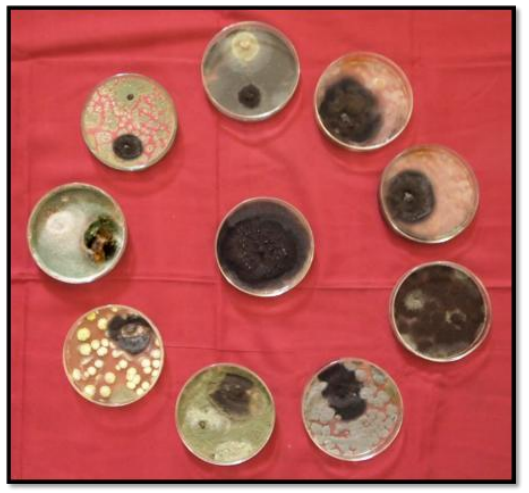

Fig.1 In vitro bioefficacy of bioagents against A. alternate

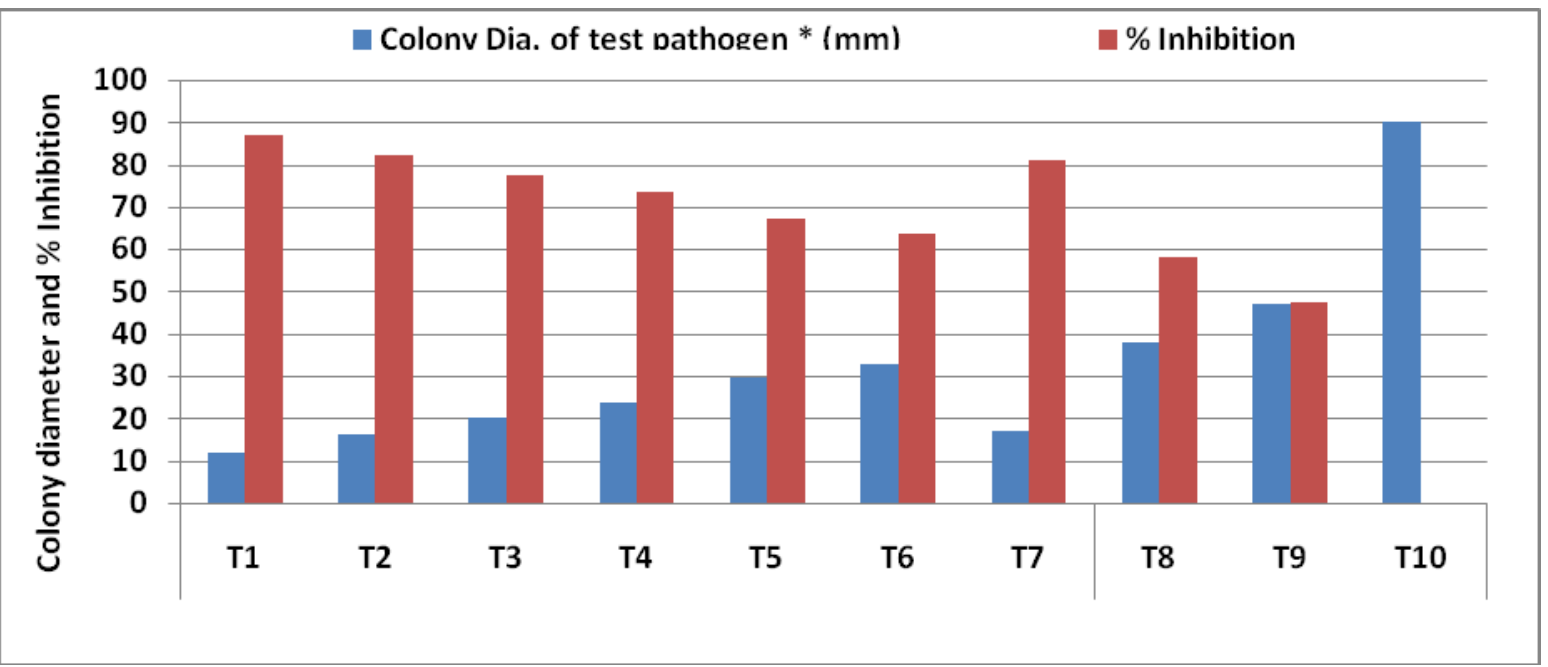

Plate,2 In vitro effect of phytoextracts at various concentrations on growth and inhibition of $A$. alternata

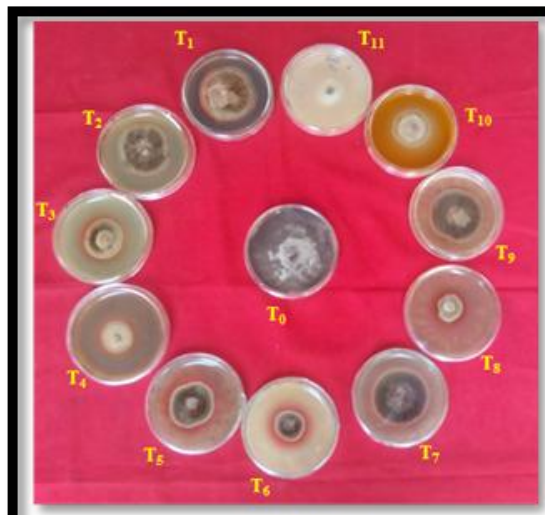

A) $\mathbf{1 0} \%$

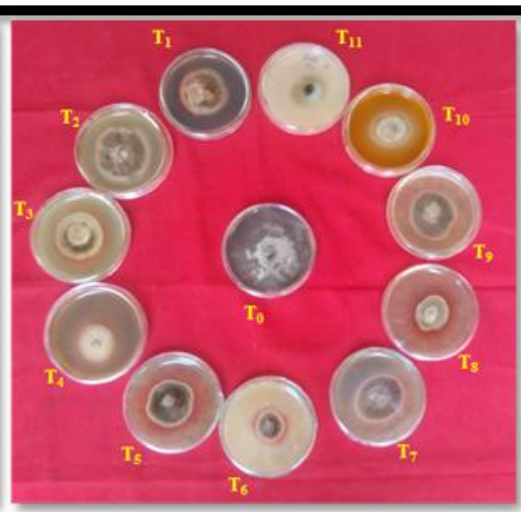

B) $15 \%$

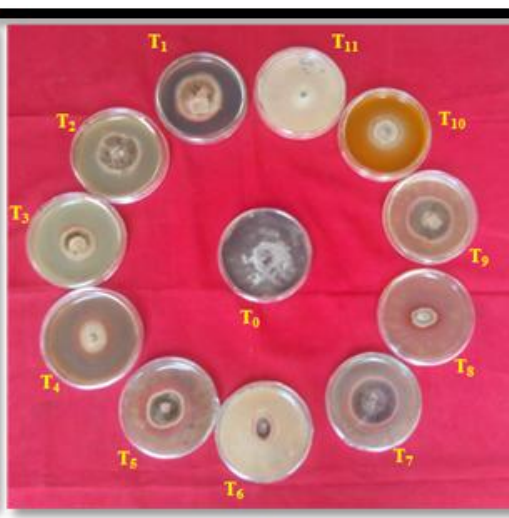

C) $20 \%$ 
Fig.2 In vitro bioefficacy of botanicals against $A$. alternate

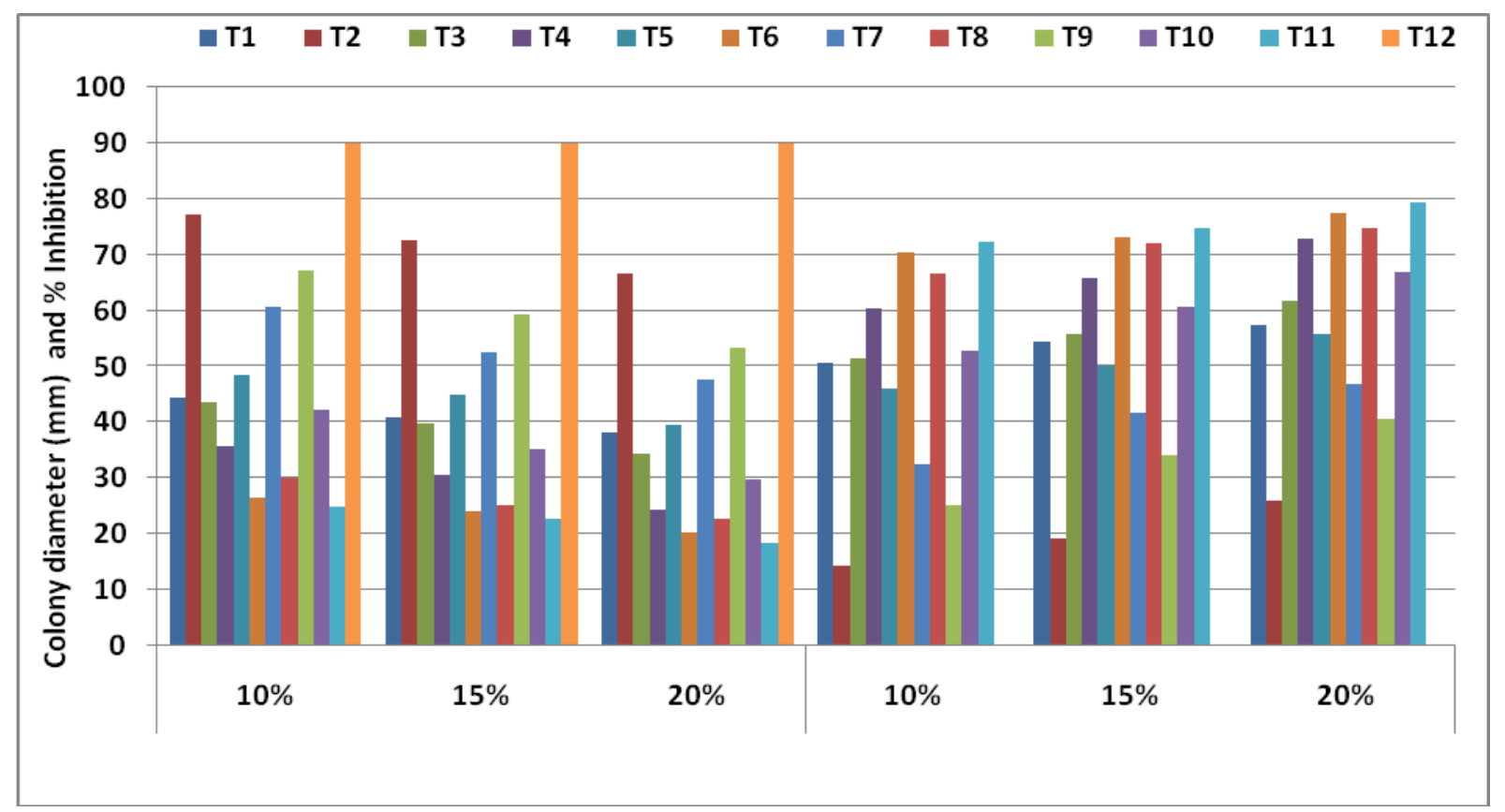

The fungistatic / antifungal action exerted by the species of Trichoderma and A. alternata and other species of Alternaria were reported by several workers, A. macrospora infecting cotton (Gholve et al., 2014), A. lini infecting linseed (Charpe et al., 2014), A. solani infecting tomato (Kharbhari et al., 2008) and A. burnsii infecting cumin (Vihol et al., 2009).

The fungistatic / antifungal action exerted by the species of Trichoderma and A. niger against A. alternata and other species of Alternaria may be attributed to their production of volatile and non-volatile substances, cell wall degrading enzymes (glucanases, B1, 3 glucanase), the phenomenon of competition, lysis and antibiosis.

In vitro evaluation of plant extracts / botanicals

Results (Table 2) revealed that all the 11 botanicals tested (each@10,15 and 20\%) exhibited a wide range of radial mycelial growth of A. alternate (Plate 2 and Fig. 2) and it was decreased drastically with increase in concentrations of the test botanicals from 10 to 20 per cent.

\section{Mycelial growth}

Average radial mycelial growth of the test pathogen was ranged from $22.00 \mathrm{~mm}$ (A. sativum) to $72.17 \mathrm{~mm}$ (Bougain veilliea $\mathrm{spp}$.). However, it was significantly least with $A$. sativum $(22.00 \mathrm{~mm})$, followed by $Z$. officinale $(23.72 \mathrm{~mm}), A$. indica $(25.94 \mathrm{~mm}), E$. globulus $(30.28 \mathrm{~mm}), C$. longa $(35.83 \mathrm{~mm}), D$. metal $(39.28 \mathrm{~mm}), V$. negundo $(41.22 \mathrm{~mm})$ and $L$. camera $(44.39 \mathrm{~mm})$ whereas $P$. pinnata, $\quad P$. hysterophorus and Bougainveilliea spp. recorded comparatively maximum mycelial growth of 53.67, 60.00 and $72.17 \mathrm{~mm}$, respectively. Results revealed that all the 11 botanicals tested exhibited a wide range of mycelial growth inhibition of A. alternata and it was decreased drastically with increase in concentrations of the test botanicals from 10 to 20 per cent 


\section{Mycelial inhibition}

Average mycelial growth inhibition of the test pathogen was ranged from $19.81 \%$ (Bougain veilliea spp.) to $75.56 \%$ (A. sativum). However, it was significantly least with $A$. sativum (75.56 \%), followed by Z. officinale (73.64 \%), A. indica (71.17\%), E. globulus (66.36\%), C. longa (60.19 \%), D. metal (56.36\%), $V$. negundo $(54.20 \%)$ and $L$. camera (50.68\%) whereas P. pinnata, P.hysterophorus and Bougainveilliea spp.recorded comparatively maximum mycelial growth of 40.37, 33.33 and $19.81 \%$, respectively.

Thus, on the basis of antifungal activity, the botanicals found most effective in the order of merit were A. sativum, Z. officinale, A. indica, E. globules, C. longa, D. metal, V. negundo, L. camera, P. pinnata, P.hysterophorus, P.hysterophorus and Bougain veilliea spp which after their further confirmation could be exploited for control of leaf spot of pomegranate (A. alternata).

In the present study, of the 11 phytoextracts A. sativum extract was found most effective which caused substantial inhibition (> 88\%) of $A$. alternata. The antifungal activity of $A$. sativum has been attributed to the presence of diallyl sulphide and other compounds like allisatin I, II and garli phytocide (Sharma and Prasad, 1980). A number of phytoextracts / botanicals have been studied and reported with potential inhibitory action against many phytopathogenic fungi, bacteria and viruses. The presence of various secondary metabolites viz., alkaloids, quaternary alkaloids, cumarins, flavanoids, steroids / terpenoids, phenolics etc with potential antifungal activity were reported in various plant extracts (Abraham et al.,1986; Chopra et al., 1992). The antifungal properties of $A$. sativum against $A$. alternate have been reported earlier by many workers (Mandhare and Suryawanshi, 2009; Balai and Ahir, 2011; Apet et al., 2014; Barman et al., 2016).

Similar effect of the test botanicals / phytoextracts against A. alternata, andother Alternaria spp. were reported earlier by several workers. Botanicals viz. A. sativum, $Z$. officinale, A. indica, E. globules, C. longa, D. metal, $V$. negundo, L. camera, $P$. pinnata, $P$. hysterophorus, $P$. hysterophorus and Bougainveilliea spp etc. were reported to cause significant mycelial growth inhibition of Alternaria spp., earlier by several workers (Anamika and Shobita, 2011; Chethana et al., 2012; Waghmare, 2012; Ganie et al., 2013).

In conclusion, all the, bio agents and botanicals evaluated in vitro were found fungistatic / antifungal against A. alternata. However, bioagents viz., $T$. viride, $T$. hamatum and A. niger; botanicals viz., $A$. sativum, Z. officinale, A. indica were most efficient with significantly highest inhibition of mycelial growth of the A. alternata causing leaf spot in pomegranate.

\section{Acknowledgement}

I greatly acknowledge to my Research Guide, Dr. D. N. Dhutraj, Head, Department of Plant Pathology, Vasantrao Naik Marathwada Krishi Vidyapeeth, Parbhani and Dr. K. T. Apet, Department of Plant Pathology, Vasantrao Naik Marathwada Krishi Vidyapeeth, Parbhani for their support during research work for the completion of my Ph.D. degree programme.

\section{References}

Abraham, Z., Bhakuni D. S., Garg H. S., Goel A. K., Mehrotra B. N. and Patnaik G. K. (1986). Screening of Indian Plants for Biological Activity. Part X11. Indian J. Exp. Biol., 24: 48-68.

Akbari, L.F. and Parakhia, A.M. (2007). Eco- 
friendly approaches to manage blight of sesame. J. Mycol. Pl. Pathol. 37(3):398400.

Anamika, P. and Sobita, S. (2011). Inhibitory effect of botanical extracts against Alternaria alternata of Aloe vera dry rot. Arc. Phytopath. Pl. Prot., 44 (15): 1462-1466.

Anonymous (2016). Area and production of horticultural crop- All India. National horticultural board.

Apet, K.T., Jagdale, J. S., Mirza, F.N. Baigh, and Chavan, P. G. More, A. S. (2014). In vitro evaluation of fungicides, botanicals and bioagents against A.alternata, causing leaf spot of Gerbera. Trends in Biosci. 7(21): 33743382 .

Arora, D.K. and Upadhyay, R.K. (1978). Effect of fungal staling growth substances on colony interaction. $\mathrm{Pl}$. Soil. 49: 685-690.

Balai, L. P. and Ahir, R. R. (2011). Evaluation of plant extracts and biocontrol agents against leaf spot disease of brinjal. Indian Phytopath. 64 (4): 378-380.

Barman, H., Roy, A., Das, S.K., Singh, N. U., Dangi, D. K. Dahun, and Tripathi, A. K. (2016). Antifungal properties of some selected plant extracts against leaf blight (Alternaria alternata) in tomato. Res. Crops. 17 (1): 151-156.

Charpe, A. M., Bhoye, B. B. and Gade, R. M. (2014). Fungistasis of Trichoderma culture filtrates against Alternaria lini, causing bud blight of linseed. J. Pl. Dis. Sci. 9 (1): 86-90.

Chethana, B. S., Ganeshan, G., Rao, A. S. and Bellishree, K. (2012). In vitro evaluation of plant extracts, bioagents and fungicides against Alternaria porri causing purple blotch disease of onion. Pest Manag. Hort. Ecos. 18(2): 194198.

Chopra, R. N., Nayer, S. L. and Chopra I. C.
(1992). Glossary of Indian Medicinal Plants, 3rd edn. Council of Scientific and Industrial Research, New Delhi. PP: 1 - 246.

Dennis, K.L. and Webster, J. (1971). Antagonistic properties of species group of Trichoderma and hyphal interaction. Trans. British Mycol. Soc. 57: 363-396.

Ganie, S. A., Ghani, M. Y., Nissar, Q. and Rehman,S. (2013a). Bioefficacy of plant extracts and biocontrol agents against Alternaria solani. African J. Microbiol. Res. 7(34): 4397-4402.

Gholve, V. M., Jogdand, S. M. and Suryawanshi, A. P. (2014). Evaluation of fungicides, botanicals and bioagents against Alternaria leaf blight caused by Alternaria macrospora in cotton. J. Cotton Res. Dev. 28 (2): 327-331.

Gohel, N. M. and Solanky, K. U. (2011). Biocontrol of $A$. alternate (Fr.) Keissler causing leaf spot and fruit rot of Chilli. J. Pl. Dis. Sci. 6(2): 200-201.

Hudge, B.V., Datar, V.V., Khalikar, P.V. and Apet, K.T. (2009). Efficacy of Trichoderma species against leaf spot (Alternariaalternata (Fr.) Keissler) of Jatropha curcas L. J. Mycol. Pl. Pathol. 39(1): 66-69.

Kharbhari, J.J., Sawant, D.M. and Deshmukh, G.P. (2008). Efficacy of Trichoderma spp. against Alternaria solani. PVK Res. J. 32 (1): 141-142.

Khosla Kishore and Bhardwaj S.S. (2013). Occurrence and incidence of important diseases of pomegranate in Himachal Pradesh.Pl. Dis. Res. 28 (1): 5-10.

Mandhare, V.K. and Suryawanshi, A.V. (2009). In vitro evaluation of botanicals against pathogen causing chickpea disease. J. Pl. Dis. Sci. 4 (1): 128-129.

Nene, Y. L. and Thapliyal, P.N. (1993). Evaluation of fungicides. In: Fungicides in Plant disease Control ( $3^{\text {rd }}$ ed.) Oxford IBH publishing co., New Delhi. PP: 331. 
Rajput, R. B., Solanky, K. U. and Kavyashree, M. C. (2013). Effect of fungal and bacterial bioagents against $A$. alternata (Fr.) Keissler invitro condition. The Bioscan. 8(2): 627-629.

Sharma, V. D. and Prasad, R. (1980). Garlic an effective antimicrobial bulb. Sci. Reptr 17: 790.

Vihol, J.B., Patel, K.D., Jaiman, R.K. and Patel, N.R. (2009). Efficacy of plant extracts, biological agents and fungicides against Alternaria Blight of Cumin. J. Mycol Pl. Pathol. 39 (3): 516519.
Vincent, J.M. (1927). Distortion of fungal hyphae in the presence of certain inhibitors Nature: 159-180.

Waghmare, M.B. (2012). Efficiency of mycotoxins of some plant extracts against Alternaria alternata (Fr.) Kessler causing leaf spot of gerbera. Current Biotica., 6(2): 240-245.

Waghunde, R.R., Patil, R. K. and Sabalpara, A. N. (2009). Antagonistic Effect of Bioagents on Alternaria Fruit Rot (Alternaria alternata) of Aonla. J. Mycol. Pl. Pathol., 39 (3): 571.

\section{How to cite this article:}

Vasudha A. Kadam, D.N. Dhutraj, D.V. Pawar and Patil, D.D. 2018. Bio Efficacy of Bio Agents and Botanicals against Alternaria alternata (Fr.) Keissler Causing Leaf Spot of Pomegranate. Int.J.Curr.Microbiol.App.Sci. 7(11): 1146-1155.

doi: https://doi.org/10.20546/ijcmas.2018.711.133 